\title{
Modern portfolio theory with sharia: a comparative analysis
}

\author{
John A. Sandwick ${ }^{1}$ [ . Pablo Collazzo ${ }^{2}$ \\ Revised: 19 August 2020 / Accepted: 7 September 2020 / Published online: 10 October 2020 \\ (c) The Author(s) 2020
}

\begin{abstract}
Despite Muslims comprising a quarter of the world's population, almost none of the $\$ 100$ trillion in professionally managed global assets are sharia compliant. Constraints such as ESG and SRI are common among pension funds, endowments and sovereign wealth funds. Typical constraints include alcohol, tobacco, weapons and environmentally damaging activities. Such securities are excluded from morally constrained portfolios. Sharia applies the same, but adds one more key constraint: securities with debt-related features. Otherwise, sharia is identical to most ethical constraints. This study shows the results of constructing optimized, multi-asset, globally allocated portfolios while respecting sharia. The construction of these portfolios follows contemporary regulatory standards and professional best practices that evolved from investment theory. Results indicate multi-asset sharia portfolios have at least equal return and risk characteristics to conventional peers, or are perhaps in some ways superior. Many Muslims profess to care about sharia, including with their savings. This study provides insight for professional asset managers in applying sharia with modern portfolio theory, which could substantially enhance wealth and asset managers seeking business in this sector.
\end{abstract}

Keywords Islamic asset management $\cdot$ Islamic wealth management $\cdot$ Portfolio investing with sharia $\cdot$ Sharia-compliant portfolio investing

\section{Introduction and relevance}

Muslims comprise about one quarter of the world's population, but as yet cannot thoroughly enjoy the benefits of modern portfolio theory (MPT). There are arguably no asset managers offering Islamic asset management on a systematic, broad basis in the world today.

Whether conventional or Islamic, the same portfolio management principles and processes would apply, namely find securities in each asset category (money market, fixed income, equities and alternatives), filter and sort them into a Buy List, and subject the Buy List to optimization within and among asset classes. These asset management functions

Pablo Collazzo

pablo.collazzo@donau-uni.ac.at

John A. Sandwick

john@sandwick.ch

1 Safa Investment Services SA, 17, chemin des Courtis, 1252 Meinier, Switzerland

2 Danube University, Dr. Karl Dorrek Straße 30, 3500 Krems, Austria have been the subject of numerous academic studies for decades, including multiple moral constraints, but none in the context of sharia.

Like people of all other faiths, Muslims save for their future. Constrained investing is common, so there should be no barriers to constructing Islamic asset management. Extending MPT to sharia-constrained investing could be useful. Market opportunities may abound for asset managers who produce services for clients who demand shariacompliant wealth and asset management.

\section{Overview of the literature}

The foundations of asset management were established by Markowitz (1952) (the efficient frontier from meansvariance optimization), Tobin (1958) (risk-free rate) and Sharpe (1964) (capital market line and the point of optimality). These foundations were supplemented by Brinson et al. (1986) (attribution analysis), Black and Litterman (1992) (multi-asset portfolios via a global equilibrium risk benchmark), and Fama (1970) (efficient markets 
hypothesis). The pantheon of literature supporting MPT is rich, varied and directly contributed to the asset management industry as we know it.

Literature on Islamic asset management is sparse. Hakim and Rashidian (2004) indicated "competitive risk adjusted return and a performance" for sharia-compliant equities vis-à-vis the entire equity market. Walkshäusl and Lobe (2012) attempted to deconstruct the sources of positive equity performance, finding sharia-compliant equities biased in certain sectors that outperformed general indexes during certain time periods. Bahloul et al. (2017) explained the diversification benefits from adding sharia constraints for conventional investors, in particular US-domiciled equity portfolios. Most recently, Camgoz et al. (2019) showed "no statistically significant differences between the risk and return characteristics of Islamic indices and their conventional counterparts," and "Islamic index investors have not incurred additional costs in the period examined" (2002-2017). This is welcome news for investors considering sharia.

Islamic fixed-income investment research is quite limited. Mosaid and Rachid Boutti (2014) indicated high and positive correlation between sukuk (Islamic bonds) and conventional bonds, which was further supported by Naifar et al. (2017), who also indicated sukuk performance is sufficiently different to indicate their positive contribution to conventional fixed-income portfolios. Subsequently, the same diversification benefits were confirmed by Hassan et al. (2018), along with evidence of high sukuk correlation to conventional bond markets.

Only two studies looked at multi-asset, optimized portfolio investing with sharia. Dewandaru et al. (2014) made such an effort, but allowed for non-sharia assets in their portfolios, essentially invalidating the utility of their work for Muslims seeking sharia-compliant investing. A similar effort was made by Dewi and Ferdian (2012), but limited only to the Malaysian and Indonesian markets.

Investing with sharia can be considered a subset of environmental, social, and governance (ESG) investing as it involves the same sorting and filtering processes to exclude certain securities. ESG investing has been the focus of much scholarship, including Kumar et al. (2018), who advocate "tilting" toward ESG in a proactive fashion rather than blunt-force exclusion. Fu et al. (2019) surveyed various ESG styles, including sharia, and conclude, “...no evidence of a performance cost for sin-free, carbon-free, or Shariah portfolios in Sharpe ratio analysis." In short, the literature indicates that constructing sharia-compliant portfolios involves the same exclusion processes involved in ESG investing, and that all-equity, sharia-compliant portfolios have no additional costs in terms of lost performance.

\section{Gap and research question}

While academic studies related to Islamic investment have been mostly confined to single-asset performance, realworld client portfolios rarely have a single asset class. Multi-asset-class optimized portfolio investing is the norm. Upon a comprehensive review of the literature, we found no study indicating the results of following MPT with the constraint of sharia in the context of multi-asset, globally allocated, optimized portfolio investing.

Most Muslims profess to care about sharia, the principles of Islam that guide spiritual but also temporal life. Beyond the well-known constraints against alcohol and pork, sharia also excludes interest on debt and investing outside the real-economy (e.g., hedge funds and derivatives). For Muslims who care about their faith, there may be a path to combine the scientific advances of MPT, but with the added constraint of respecting the doctrine of sharia.

This combination is examined here. We intend to answer the question, "what are the performance (and risk) characteristics of multi-asset optimized portfolios comprising sharia-compliant securities as measured by contemporary risk and reward metrics, and how does this performance compare to conventional (non-Islamic) peer portfolios that are equally constructed?".

\section{Methodology}

This study first examines the factors that would make Islamic asset management possible, considering those theoretical elements of MPT that give managers the tools to responsibly optimize multi-asset portfolios and whether they contradict sharia. This is followed by an examination of those steps commonly used to filter and sort securities to meet regulatory and professional standards, narrowing the existing availability of sharia-compliant securities to a potential Buy List. It concludes with the construction of optimized, multi-asset sharia-compliant portfolios for a hypothetical "common man," and compares performance and risk to conventional peers.

\section{Modern portfolio theory and sharia}

MPT is agnostic. There are no spiritual considerations in constructing the efficient frontier, determining the risk-free rate, or building the capital market line. Professional asset managers have taken these fundamental theoretical building blocks of MPT and articulated them into a common 
asset management process. Over the last several decades, regulators have imposed constraints on managers that limited their efforts within the confines of the "prudent man" laws common everywhere.

Asset management as a global enterprise is relatively homogeneous. Few asset managers deviate from a practice involving identical steps: client identification and contracting, strategy selection, portfolio construction, investing, and then monitoring, rebalancing and reporting. These same steps are taken whether the asset manager is in London or Madrid, Sao Paulo or Tokyo. As in other professional practices, asset managers usually stick to operating within industry- and regulatory-defined parameters.

Where in this process is there possible violation of sharia? Muslims believe in the well-known constraints on alcohol, pork, weapons and the like. But, a strong prohibition exists against interest, or riba. Interest appears almost everywhere in conventional asset management, from shares of banks to bonds of every kind. Importantly, sharia also restricts equities to companies with no more than $25 \%$ balance sheet leverage. Already one can conclude that security screening is essential to achieve sharia compliance.

There is also a prohibition against investing in anything but the "real" economy. That means derivative securities are almost entirely absent from Islamic asset management, which by extension excludes hedge funds and structured products.

It should be noted that the risk-free rate (RFR) is embedded in the capital asset pricing model (CAPM), a fundamental tool for financial asset pricing. Some might conclude the RFR implies a base cost of capital involving interest. Fortunately, scholars investigated CAPM and determined it is either irrelevant because the RFR can be easily substituted by Muslims with sharia-compliant risk-free references (e.g., government sukuk rates, or Islamic inter-bank lending rates), or it is indeed relevant, but substituting US Treasuries with a sharia-acceptable rate produces the same results (Hakim et al. 2016).

As pointed out by Hazny et al. (2017), “...the traditional CAPM is a relevant model in Islamic finance. Most of the assumptions underlying the Markowitz's Mean-Variance Portfolio Theory are not contradictory to shariah principles." For the present there are no evident contradictions in contemporary asset allocation theory and sharia. MPT and essentially most or all of its derivatives can be freely used to construct optimized portfolios for both Muslims and nonMuslims alike.

\section{The Islamic investible universe}

The real difference arguably lies in security selection. As indicated, sharia prohibits bonds, hedge funds, and conventional financial entities (banks, insurance companies), plus highly leveraged companies. The market portfolio for Muslims is by nature different than the conventional market portfolio because of these constraints.

Among the four classic asset categories, one must search for sharia-compliant securities. For cash substitutes (money market), one finds murabaha funds with ease. In fixed income, there is now a universe of around $\$ 500$ billion in sukuk (widely called Islamic bonds), plus a handful of trade finance investment products. Among equities, one simply takes a sharia screening service to choose among shares (e.g., the Islamic indexes provided by MSCI, Dow Jones, or IdealRatings). Islamic alternative investments are more complicated, in particular for smaller investors, where choices are mostly among commodity ETCs and some REITs. For larger amounts, there are examples of investing in natural resources and private equity with full sharia compliance.

Most portfolios for conventional, non-Islamic retail ("common man") and even many high-net-worth investors are done via mutual funds and ETFs. Since MPT can apply to virtually all investors, Muslims would be no different. They, too, will or should mostly invest via mutual funds and ETFs, but only those certified sharia compliant.

A search for the sharia-compliant investible universe, however, gets complicated. Starting with Morningstar and Lipper, one finds several hundred securities noted, but one imagines there must be more. Refinitiv does better, but Bloomberg turns out to be the sole provider of comprehensive data on the sharia mutual fund and ETF sector through its ISLM service. Here one can download data on up to 1250 securities, resulting in about 850 such securities when duplicate share classes are removed. These comprise over $\$ 63$ billion in AUM (Table 1).

While this is paltry compared to the 114,000 mutual funds and ETFs worldwide, with over \$49 trillion AUM, it is a start.

Regulators and professional best practice conspired for decades to establish adoption requirements for mutual funds and ETFs, in the process insuring open-architecture investing is maintained. A survey of notable global asset managers (UBS in November 2015; and Credit Suisse, HSBC, Pictet and Mirabaud in May 2014) indicates all initially utilize quantitative and qualitative factors to filter, screen and sort the universe and evolve their own internal Buy Lists. Factors include manager AUM, track record and domiciliation, among others. Occasionally some securities are excluded from some or all of the filters for various reasons, for example ETFs and ETCs, which by nature are mostly liquid and unmanaged.

Applying these screens to the Islamic investible universe of mutual funds and ETFs results in around 160 securities that meet relatively strict adoption requirements, with $\$ 46$ billion AUM. But, if the objective is to create a diversified global allocation for a "common man" investor in Saudi 
Table 1 The Islamic investible universe. Source: Authors' work, data from Bloomberg, dated 31 December 2017

\begin{tabular}{|c|c|c|c|c|c|c|c|c|}
\hline $\begin{array}{l}\text { Fund exclusion } \\
\text { criteria }\end{array}$ & Description & $\begin{array}{l}\text { Number of } \\
\text { funds }\end{array}$ & $\begin{array}{l}\% \Delta \text { from } \\
\text { total funds } \\
(\%)\end{array}$ & $\begin{array}{l}\text { Remaining } \\
\text { funds }\end{array}$ & $\begin{array}{l}\text { Remaining } \\
\text { AUM (\$ mil- } \\
\text { lions) }\end{array}$ & $\begin{array}{l}\$ \Delta \text { from previ- } \\
\text { ous }\end{array}$ & $\begin{array}{l}\% \Delta \text { from } \\
\text { total AUM } \\
(\%)\end{array}$ & $\begin{array}{l}\% \\
\text { Remain- } \\
\text { ing AUM } \\
(\%)\end{array}$ \\
\hline Initial total & $\begin{array}{l}\text { Includes dupli- } \\
\text { cates }\end{array}$ & 1176 & & 1184 & $\$ 191,586$ & 191,587 & & \\
\hline Duplicates & $\begin{array}{l}\text { Remove dupli- } \\
\text { cates, new } \\
\text { total }\end{array}$ & 321 & -27.30 & 855 & $\$ 63,183$ & $-128,404$ & -67.02 & 100.00 \\
\hline Domicile & $\begin{array}{l}\text { Country of } \\
\text { domicile has } \\
\text { exchange } \\
\text { controls }\end{array}$ & 211 & -24.68 & 644 & $\$ 59,368$ & -3814 & -6.04 & 93.96 \\
\hline AUM & $\begin{array}{c}\text { AUM }<\text { USD } \\
50 \text { million }\end{array}$ & 477 & -55.79 & 167 & $\$ 52,146$ & -7222 & -11.43 & 82.53 \\
\hline Liquidity & $\begin{array}{l}\text { Pricing fre- } \\
\text { quency more } \\
\text { than one } \\
\text { month }\end{array}$ & 12 & -1.40 & 155 & $\$ 46,722$ & -5425 & -8.59 & 73.95 \\
\hline Track record & $\begin{array}{l}\text { Years since } \\
\text { incep- } \\
\text { tion }<2 \text { years }\end{array}$ & 18 & -2.11 & 137 & $\$ 44,885$ & -1837 & -2.91 & 71.04 \\
\hline ETF & $\begin{array}{l}\text { Add } \\
\text { ETFs }<\$ 50 \\
\text { million }\end{array}$ & 13 & 1.52 & 150 & $\$ 45,177$ & 291 & 0.46 & 71.50 \\
\hline Exempt funds & $\begin{array}{l}\text { Add funds } \\
\text { exempt from } \\
\text { liquidity and } \\
\text { track record } \\
\text { criteria }\end{array}$ & 8 & 0.94 & 158 & $\$ 46,391$ & 1214 & 1.92 & 73.42 \\
\hline $\begin{array}{l}\text { Local invest- } \\
\text { ments }\end{array}$ & $\begin{array}{l}\text { Remove all } \\
\text { local invest- } \\
\text { ments }\end{array}$ & 94 & 10.99 & 64 & $\$ 15,379$ & $-31,012$ & -49.08 & 24.34 \\
\hline $\begin{array}{r}\text { Investible } \\
\text { universe }\end{array}$ & & 64 & 7.49 & & $\$ 15,379$ & & & 24.34 \\
\hline
\end{tabular}

Arabia, for example, one must eliminate local securities (presuming the investor is already heavily or entirely allocated to local assets, which is common), plus remove securities in niche markets that are unavailable or inappropriate for the same "common man" investor.

The result of these filtering and sorting processes is nearly 60 securities with just under $\$ 15$ billion AUM, relatively well distributed among the four classic asset categories.
Importantly, these securities meet both regulatory and professional standards for suitability, e.g., they have size, history, liquidity and deliverability across borders for booking into client accounts. Combined, they comprise an initial Islamic investible universe (Table 2).

This Buy List is not unreasonable. Among the major asset management banks in Switzerland, it is common to see accounts under discretionary management allocated
Table 2 The Islamic investible universe, filtered and sorted. Source: Authors' work, data from Bloomberg, dated 31 December 2017

\begin{tabular}{lclcr}
\hline Asset class & $\begin{array}{l}\text { Number of } \\
\text { funds }\end{array}$ & \% of funds (\%) & AUM (millions USD) & \% of AUM (\%) \\
\hline Money market & 7 & 12 & 1171.19 & 7.86 \\
Fixed income & 13 & 23 & 1332.43 & 8.94 \\
Equity & 26 & 46 & 6850.74 & 45.97 \\
Alternative & 7 & 12 & 5099.98 & 34.22 \\
Mixed allocation & 4 & 7 & 448.43 & 3.01 \\
Total & 57 & 100.00 & $\$ 14,902.77$ & 100.00 \\
\hline
\end{tabular}


to $12,15,22$ or even 28 positions, most or all comprising mutual funds and ETFs. These portfolios are globally allocated, invested in each asset category, and optimized using the same tools and processes commonly found among asset managers everywhere. We seek to construct an identical portfolio, but Islamic.

\section{Security selection and portfolio optimization}

Armed with the above-defined shortlist, the process of security selection proceeds. The 60-month (5-year) data history of each security is run through standard security measurement software to determine their respective performance and risk. Typically, these involve the following measures, which are used to eliminate obvious poor performers or other outliers (Table 3).

At this point, an investment strategy must be chosen. Here, it is assumed the underlying hypothetical investor seeks a growth investment strategy (among the three common strategies found among "common man" investors representing low-, medium- and higher-risk investing, e.g., income, balanced and growth). To insure asset allocation and security purchase parameters are met, we assume an initial invested balance of $\$ 5$ million (defining in the process a relatively prosperous individual, but not among the wealthiest or poorest of investors).

Instead of deriving an allocation using Investment Policy Statement metrics and inputs from a CIO or Chief

Table 3 Measurements for short listing securities. Source: Authors' own elaboration

\begin{tabular}{l}
\hline Return \\
\hline Total return \\
Maximum return \\
Minimum return \\
Mean return (annualized) \\
Mean excess return (annualized) \\
Risk \\
Standard deviation (annualized) \\
Downside risk (annualized) \\
Skewness \\
VaR 95\% (ex post) \\
Tracking error (annualized) \\
Risk/return \\
Sharpe ratio \\
Jensen alpha \\
Information ratio \\
Treynor measure \\
Beta (ex post) \\
Correlation \\
Capture ratio \\
\hline
\end{tabular}

Economist, a basic initial allocation is selected for simplicity (Table 4).

All classic asset categories are represented, including a division among equities that relatively fairly represents their respective market capitalizations. The growth strategy is achieved through a preponderance of riskier equity and alternative investments, and a minority of fixed-income securities. Looking at a contemporary average of allocations by asset categories among well-known global asset managers (the global growth strategy multi-asset portfolio mutual funds from Credit Suisse, Franklin Templeton, UBS and Fidelity), the "guessed" initial allocation is within reasonable ranges (Table 5).

The next step is optimizing within asset categories. Securities in each asset category are uploaded into a standard optimization software (in this case Bloomberg PORT). However, asset allocation theory must be constrained by regulatory concerns and professional best practice. For example, there are common restrictions on concentration in any single position, usually from 7 to $15 \%$ of a total portfolio. And, optimization software can be unruly. Portfolio managers know there are cases when unconstrained optimization allocates either or both of very large or very small positions within a portfolio. Given a $\$ 5$ million initial account balance, allocation of $25 \%$ or $0.50 \%$ of a portfolio in a single security is unrealistic, the former due to concentration risk and the latter due to the inability to clear small-sized tickets (i.e., an optimization exercise that recommends a $0.25 \%$

Table 4 Initial basic allocation by asset category. Source: Authors' own elaboration

\begin{tabular}{|c|c|c|c|}
\hline Portfolio size: & $\begin{array}{l}\% \text { of } \\
\text { Asset } \\
\text { Cat- } \\
\text { egory }\end{array}$ & $\%$ Portfolio & $\$ 5,000,000$ \\
\hline Growth portfolio & & & Allocation \\
\hline Money market & & $5 \%$ & $\$ 250,000$ \\
\hline Fixed income & & $20 \%$ & $\$ 1,000,000$ \\
\hline Equity & & $65 \%$ & $\$ 3,250,000$ \\
\hline Developed market equities & $82 \%$ & & $\$ 2,670,200$ \\
\hline Developing market equities & $18 \%$ & & $\$ 579,800$ \\
\hline Alternative & & $10 \%$ & $\$ 500,000$ \\
\hline Total & & $100 \%$ & $\$ 5,000,000$ \\
\hline \multirow{6}{*}{$\begin{array}{l}\text { Table } 5 \text { Average allocation of } \\
\text { global growth portfolio funds. } \\
\text { Source: Authors' work, data } \\
\text { from Bloomberg, dated } 31 \\
\text { December } 2017\end{array}$} & \multicolumn{2}{|c|}{ Asset category } & $\begin{array}{l}\text { Average } \\
\text { allocation } \\
(\%)\end{array}$ \\
\hline & \multicolumn{2}{|c|}{ Money market } & 2.16 \\
\hline & \multicolumn{2}{|c|}{ Fixed income } & 19.23 \\
\hline & \multicolumn{2}{|c|}{ Equity } & 73.26 \\
\hline & \multicolumn{2}{|c|}{ Alternative } & 5.44 \\
\hline & \multicolumn{2}{|c|}{ Total } & 100.00 \\
\hline
\end{tabular}


position results in a $\$ 12,500$ purchase order for a $\$ 5$ million portfolio, where such an order is usually unfeasible or impossible to clear due to cost or fund manager limits).

Further constraints on position size relate to asset category. It is unnecessary to crowd six or eight positions in the money market category, but at the same time unrealistic to have only one mutual fund or ETF for either developedmarket or emerging market equities. In each case a judgment must be made on the minimum and maximum number of securities selected in each asset category.

Within Bloomberg PORT, optimization is conditioned by the proprietary Bloomberg active total risk process, which is described by Bloomberg as, "Ex ante (predicted) portfolio tracking error (standard deviation of portfolio active return based on Bloomberg multi-factor risk model), expressed in \%." Ex ante is used because of its potential for predictive capabilities. Bloomberg PORT (and most other optimization programs) also allows user inputs for risk models. For the cash and fixed-income categories, the fixed-income model is chosen, while equities use the Bloomberg global equity fund risk model. Such models contain proprietary Bloomberg "black box" estimations for expected performance and risk in global asset markets.

A sample of this initial allocation process for the approved list of developed-market equity funds and ETFs is indicated in Table 6.

All 18 of the shortlisted Islamic mutual funds and ETFs from this asset category are represented, although optimization indicates several purchase orders well below a stated minimum limit of $\$ 50,000$. Subsequent optimization of a combined portfolio of developed and developing market equity funds eliminates small orders, and results in a total of nine positions for the equity category of the portfolio.

It is to be remembered that optimization involves measuring the correlation among all securities to create an optimal, forward-looking allocation in each asset category. After such optimization is done at the category level, a complete allocation among all asset categories is performed. The result should be an optimized portfolio representing each asset category, adhering to the input constraints for regulatory and professional best practice reasons.

Before final optimization, additional rules are input. For example, the broader investment strategy must be represented by ratios of asset categories that reflect the strategy's defined risk objectives. The fixed-income category, for example, will be constrained within a range of 10-35\% of total assets to insure a minority of these relatively lowrisk securities are present in the final allocation. Equities are equally constrained. Minority categories such as money market and alternatives are given limits above $0 \%$ but below $5 \%$ per position to maintain their minority status.

After optimizing within and among asset categories using these new rules, a final allocation is established through the same optimization process at the portfolio level (Table 7).

The allocations per asset category are unsurprisingly close to the averages among the conventional mutual fund
Table 6 Sample, optimization results for developed market equities. Source: Authors' work, data from Bloomberg, dated 31 December 2017

\begin{tabular}{lllccrc}
\hline Security & Type & Regional focus & $\begin{array}{l}\text { Initial } \\
\text { allocation } \\
(\%)\end{array}$ & $\begin{array}{l}\text { Optimized } \\
\text { allocation } \\
(\%)\end{array}$ & Buy order & $\begin{array}{l}\text { \% of } \\
\text { portfolio } \\
(\%)\end{array}$ \\
\hline AMAGX US & Fund & International equities & 5.56 & 13.83 & 369,289 & 7.39 \\
AMANX US & Fund & International equities & 5.56 & 13.57 & 362,346 & 7.25 \\
IMANX US & Fund & International equities & 5.56 & 13.43 & 358,608 & 7.17 \\
BAJAMJE AB & Fund & Japanese equities & 5.56 & 13.39 & 357,540 & 7.15 \\
ISDU LN & ETF & US equities & 5.56 & 13.38 & 357,273 & 7.15 \\
ADJEX US & Fund & International equities & 5.56 & 13.29 & 354,870 & 7.10 \\
ISDW LN & ETF & International equities & 5.56 & 3.60 & 96,127 & 1.92 \\
BAJALKH AB & Fund & International equities & 5.56 & 2.11 & 56,341 & 1.13 \\
ALEURTR AB & Fund & European equities & 5.56 & 1.89 & 50,467 & 1.01 \\
OACREQU SJ & Fund & International equities & 5.56 & 1.82 & 48,598 & 0.97 \\
ALUSTRA AB & Fund & US/North American equities & 5.56 & 1.82 & 48,598 & 0.97 \\
SCUSEPA LX & Fund & US/North American equities & 5.56 & 1.82 & 48,598 & 0.97 \\
TSGEAAU LX & Fund & International equities & 5.56 & 1.81 & 48,331 & 0.97 \\
HSBCGLE LX & Fund & International equities & 5.56 & 1.79 & 47,797 & 0.96 \\
SWIPIUB LX & Fund & International equities & 5.56 & 1.37 & 36,582 & 0.73 \\
ALHCTRE AB & Fund & Health Care equities & 5.56 & 0.46 & 12,283 & 0.25 \\
BNPIEOP LX & Fund & International equities & 5.56 & 0.31 & 8278 & 0.17 \\
BAJATEE AB & Fund & European equities & 5.56 & 0.31 & 8278 & 0.17 \\
Total & & & 100.00 & 100.00 & $\$ 2,670,200$ & 53.40 \\
\hline & & & & & &
\end{tabular}


Table 7 Final optimized multi-asset global Islamic portfolio allocation. Source: Authors' work, data from Bloomberg, dated 31 December 2017

\begin{tabular}{|c|c|c|c|c|}
\hline Security & Investment focus & $\%$ of portfolio $(\%)$ & $\%$ of category $(\%)$ & \$ Allocation \\
\hline ALCOMUS AB & Al-Rajhi-Commodity Fund USD & 1.17 & 1.17 & 58,500 \\
\hline JDSUKUK AB & Jadwa Global Sukuk & 4.66 & & 233,000 \\
\hline WISEX US Equity & Azzad Wise Capital Fund & 4.39 & & 219,500 \\
\hline EFHGSPF LX & EFH Global Sukuk Plus Fund & 4.60 & & 230,000 \\
\hline BPIHIPA LX & BNP Paribas Islamic Hilal Income Fund & 4.58 & & 229,000 \\
\hline EMDYLQR JY & Emirates Global Sukuk Fund & 4.65 & 22.88 & 232,500 \\
\hline AMANX US & International equities & 9.96 & & 498,000 \\
\hline IMANX US & International equities & 9.70 & & 485,000 \\
\hline BAJAMJE AB & Japanese equities & 8.97 & & 448,500 \\
\hline ISDU LN & US equities & 10.33 & & 516,500 \\
\hline ADJEX US & International equities & 10.18 & & 509,000 \\
\hline AMAGX US & International equities & 10.20 & & 510,000 \\
\hline PUBASIT MK & Emerging market equities & 12.97 & 72.31 & 648,500 \\
\hline SPAL LN & Source Physical Palladium P-ETC & 1.83 & & 91,500 \\
\hline SCREITS LX & SC Global Real Estate Fund & 1.81 & 3.64 & 90,500 \\
\hline Total & & 100.00 & 100.00 & $\$ 5,000,000$ \\
\hline
\end{tabular}

peers, suggesting that the above optimization exercise using sharia-compliant securities has achieved some degree of conformity to conventional asset allocation. It is the result of a defined process, using common allocation rules and limits.

How would this portfolio have performed over the 5-year measurement period? Back testing the data is illustrative (Fig. 1).

The above portfolio is entirely passive. There were no investment decisions other than those defined at the beginning. No effort was made to rebalance at any time. To address this, a second portfolio is then constructed as a proxy for active management. Here, the midpoint between asset category ranges for the four comparative conventional peer portfolios is established throughout the 60-month investment period. These midpoints are set for the Islamic portfolio, with the performance data again back tested (the Islamic "active" portfolio). However, this time the backtested results are compared to the performance of the conventional peers (Fig. 2).

In this case, the Islamic proxy for active management has reasonably outperformed its conventional peers in multiple categories. Total and mean annualized returns enjoy fairly substantial outperformance. Both Sharpe and Treynor measures are superior. Overall, the data indicate the proxyactive sharia-compliant portfolio is superior in almost every measure (Table 8).

It can be said, however, that comparing a proxy for a managed Islamic portfolio to managed conventional peer-strategy portfolio funds is incomplete. In addition to the proxy being an imperfect substitute for actual
Fig. 1 5-year performance of an optimized Islamic Growth portfolio. Source: Authors' work, data from Bloomberg, dated 31 December 2017

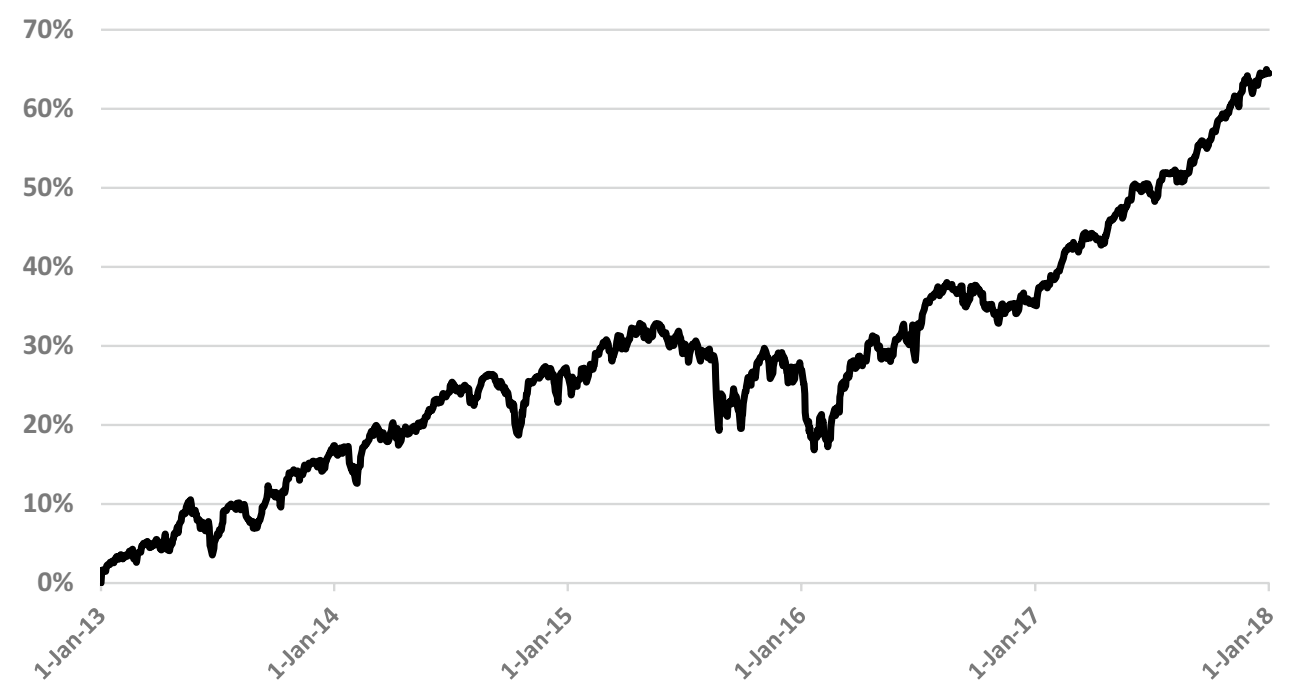




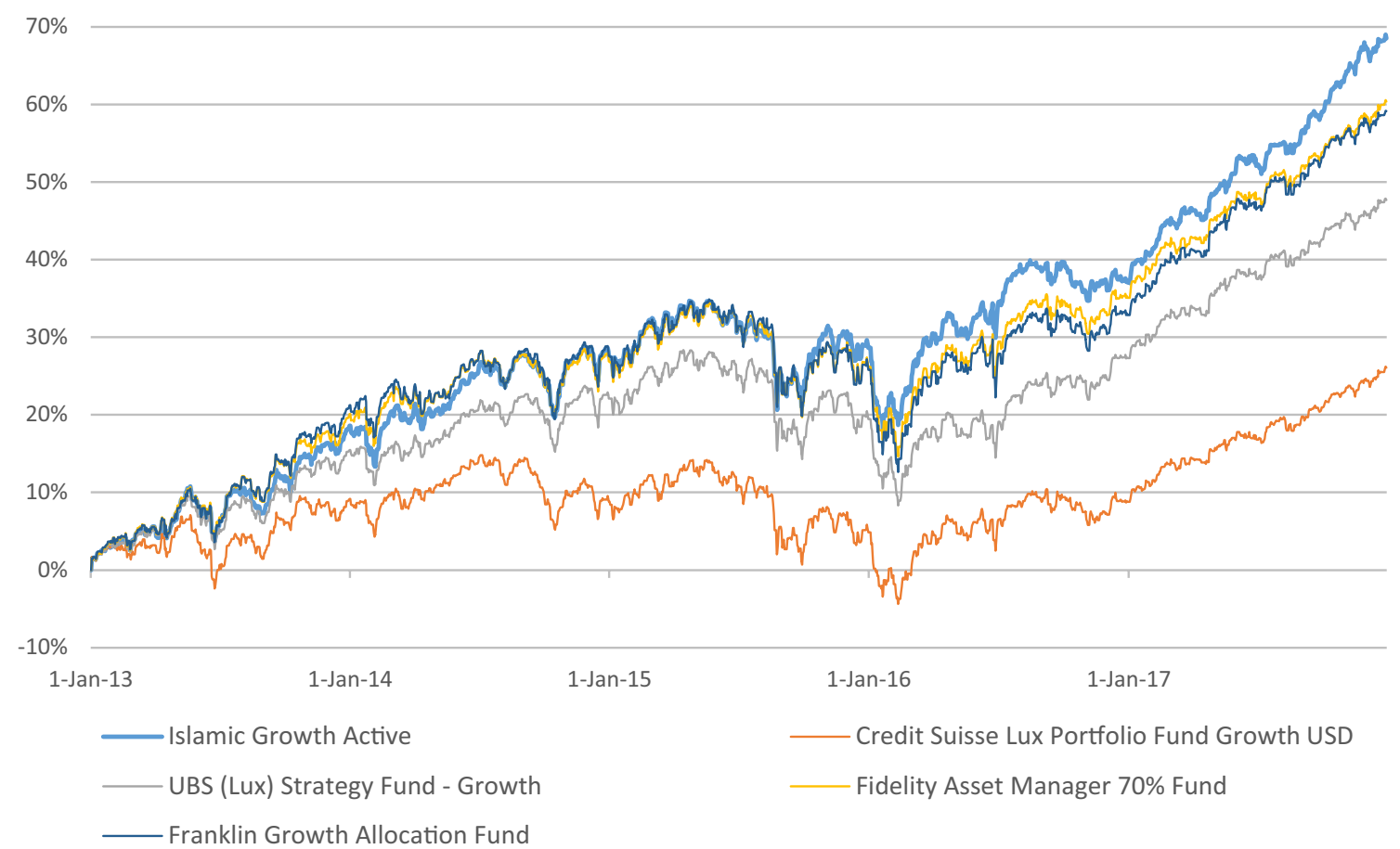

Fig. 2 5-year performance of an optimized Islamic "active" growth portfolio versus conventional peers. Source: Authors' work, data from Bloomberg, dated 31 December 2017

Table 8 Performance, risk and return: Islamic Growth (active) versus peer conventional mutual funds. Source: Authors' work, data from Bloomberg, dated 31 December 2017

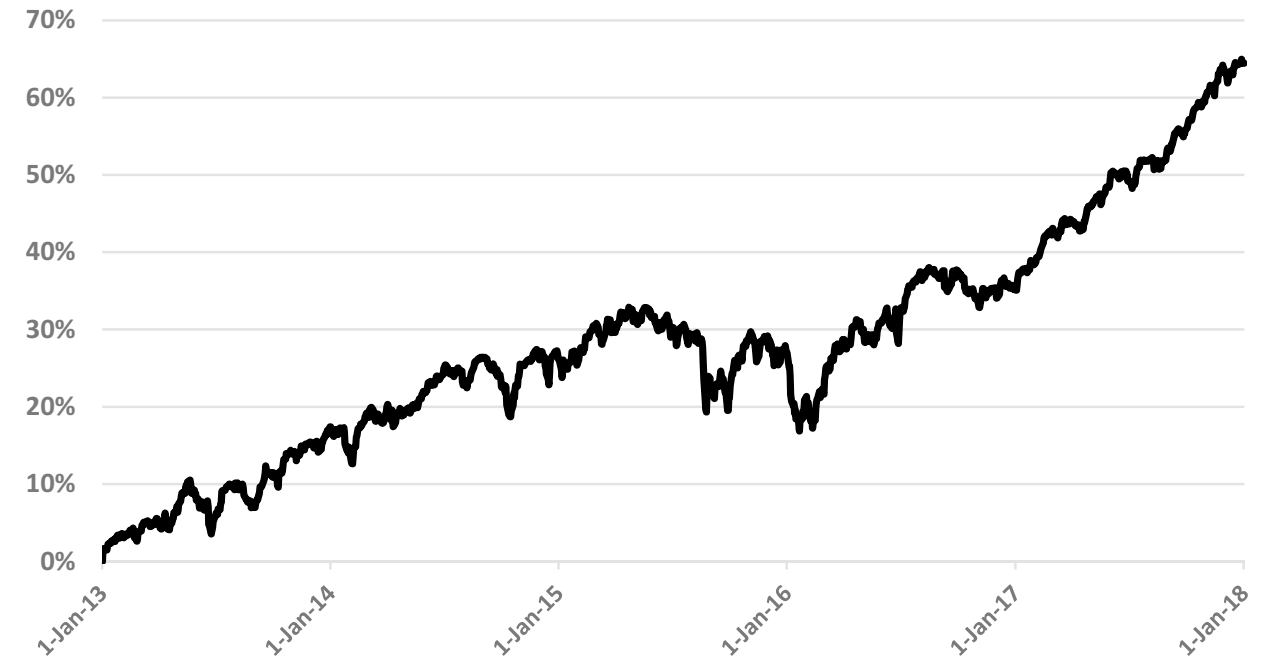

Source: Authors' work, data from Bloomberg, date 31 December 2017 management, there are other considerations. Among them are costs. All four of the conventional peers indicate net performance after these expenses, while the Islamic proxy portfolio does not. Not noted are the total expense ratios of the conventional peers, but they are thought to be at least
$1.5 \%$ per year. Over the 5 -year measured period, this would indicate a substantially higher performance (up to $7 \%$ or more, depending on the TER) than indicated here. Still, even considering the level of possible costs, the Islamic portfolio would have outperformed the conventional peer 
portfolio mutual funds on total and mean annualized returns. And, risk measurements would remain superior.

Another possible comparison would be constructing a conventional portfolio identically to the Islamic portfolio, both on a static basis, and comparing the outcomes. Here, the process would be the same:

1. Identifying the entire investible universe of conventional mutual funds and ETFs in each asset category

2. Sorting and filtering the universe to reduce the dataset to a minimum acceptable number of investment securities in each asset category

3. Using the same optimization methodology to create a Buy List of securities in each asset category

4. Subjecting the Buy List to the same initial portfolio allocation (i.e., fixed initial weights in each category), then using the Bloomberg optimization module to derive a final optimized conventional portfolio that includes each of the asset categories

5. Back-testing the conventional, optimized portfolio, then comparing that to the Islamic Growth portfolio (passive) and the conventional peers

For the defined date range, there were 375,262 total mutual funds and ETFs in the Bloomberg universe of conventional mutual funds (including multiple share classes). Bloomberg, however, limits fund analysis to no more than 5000 at any time. Thankfully, following the process to eliminate duplicate share classes, then filter and sort, the resulting eligible conventional funds numbers 4815 , again representing all classic asset categories. And, these 4815 funds represent over \$21 trillion in total AUM, more than sufficient for constructing an optimized, globally allocated, multi-asset conventional portfolio.

In this case, the same initial and basic allocation template is used as a starting point. Funds from each asset category are input into Bloomberg, followed by the identical optimization process within and among asset categories. Bloomberg's optimization module recommends the following final allocation (Table 9).

A comparison between the optimized Islamic and conventional allocations is illustrative (Table 10).

Evident are allocations in money market and fixedincome categories that are relatively comparable. Where the two allocations substantially differ is in equities and alternatives. Equities in the conventional allocation are more than seven percentage points less than in the Islamic, while alternatives are almost nine percentage points greater. This likely reflects the vastly greater number of alternatives available to conventional investors. However, the two asset categories combined are nearly identical in terms of total allocation within the portfolio at $76 \%$ and $77 \%$, respectively.

It can be argued that both the Islamic and conventional static portfolios have been identically constructed in line with contemporary asset allocation processes. Neither pretend to be managed. Both are exhibited without fees and

Table 9 Final optimized multi-asset global conventional (passive) portfolio allocation. Source: Authors' work, data from Bloomberg, dated 31 December 2017

\begin{tabular}{|c|c|c|c|}
\hline Asset categories & Securities & $\%$ of portfolio $(\%)$ & $\%$ of category $(\%)$ \\
\hline \multicolumn{4}{|l|}{ Money market } \\
\hline GRFXX US Equity & FEDERATED GOVT RESERVE-P & 1.57 & \\
\hline SSIXX US Equity & STATE ST INST LIQ RES-PREM & 1.22 & 2.79 \\
\hline \multicolumn{4}{|l|}{ Fixed income } \\
\hline DRCAX US Equity & DREYFUS CA AMT-FR MUNI-Z & 6.87 & \\
\hline FIIGX US Equity & FIRST INVEST INV GRD-A & 5.31 & \\
\hline MSNYX US Equity & MFS NEW YORK MUNICIPAL-A & 3.90 & \\
\hline PRHAX US Equity & PGIM MUNI HIGH INCOME-A & 3.92 & 20.00 \\
\hline \multicolumn{4}{|l|}{ Equity } \\
\hline JKD US Equity & ISHARES MORNINGSTAR LARGE-CA & 13.85 & \\
\hline VHT US Equity & VANGUARD HEALTH CARE ETF & 13.85 & \\
\hline BOSVX US Equity & BRIDGEWAY OMNI S/C VALUE FD & 12.79 & \\
\hline ACWD LN Equity & SPDR ACWI & 12.91 & \\
\hline GDISAAI LX Equity & JUPITER JGF-INDIA SEL-L USD & 7.80 & \\
\hline IIF US Equity & MORGAN STANLEY INDIA INVEST & 3.80 & 65.00 \\
\hline \multicolumn{4}{|l|}{ Alternatives } \\
\hline PACL LN Equity & PACIFIC ALLIANCE CHINA LAND & 6.84 & \\
\hline DFITX US Equity & DFA INTL RL EST SECS & 5.37 & 12.21 \\
\hline Total & & 100.00 & 100.00 \\
\hline
\end{tabular}


Table 10 Comparison of Islamic versus conventional growth strategy allocations. Source: Authors' work, data from Bloomberg, dated 31 December 2017

\begin{tabular}{lccc}
\hline Category & $\begin{array}{l}\text { Islamic } \\
\text { \% of portfolio (\%) }\end{array}$ & $\begin{array}{l}\text { Conventional } \\
\text { \% of portfolio (\%) }\end{array}$ & Variance (\%) \\
\hline Money market & 1.17 & 2.79 & -1.62 \\
Fixed income & 22.88 & 20.00 & 2.88 \\
Equities & 72.31 & 65.00 & 7.31 \\
Alternatives & 3.64 & 12.21 & -8.57 \\
Total & 100.00 & 100.00 & \\
\hline
\end{tabular}

costs. The allocations were processed using the same iterative functions of Bloomberg's optimization black box, where both were subjected to potentially millions of calculations to test covariance and achieve optimality using the same expected risk and return parameters.

Results can be compared and analyzed. Immediately evident is that the passive conventional portfolio is the top performer (Fig. 3).

Mean annualized return of the conventional growth portfolio is nearing $20 \%$ higher than Islamic Growth, and more so against the conventional peers. While its standard deviation is higher than Islamic Growth, it is well within the range of the conventional peers. Sharpe ratio for conventional growth is well above conventional peers, and a few percentage points higher than Islamic Growth (Table 11).
Importantly, the conventional growth portfolio indicates slightly superior levels of capture ratio, but as measured by information ratio, the conventional growth portfolio indicates sustained benchmark outperformance versus the Islamic Growth portfolio. The Jensen's alpha measure is nearly $40 \%$ higher than Islamic Growth, indicating superior reward of return for the measurable risk.

Both the conventional growth and the Islamic Growth are perfectly unmanaged portfolios, with no human intervention after the initial optimization and allocation. While conventional Growth (passive) beats Islamic Growth (passive), one should bear in mind that both the passive and active versions of Islamic Growth showed superior performance and risk measures compared to the conventional managed peers.

No benchmarking was added to the analyses above. The principal competition of Islamic wealth and asset management is presumably conventional wealth and asset management, so they were compared against each other. One could attempt to construct a hybrid benchmark for the Islamic portfolio, where there are abundant sharia indexes commercially available for both fixed-income and equity markets. More problematic are indexes for alternative investments, which as yet do not exist for sharia investors. However, it was considered the benchmarking exercise would not add additional insights in an effort to compare sharia versus conventional portfolio investing, where head-on-head comparisons are the goal.

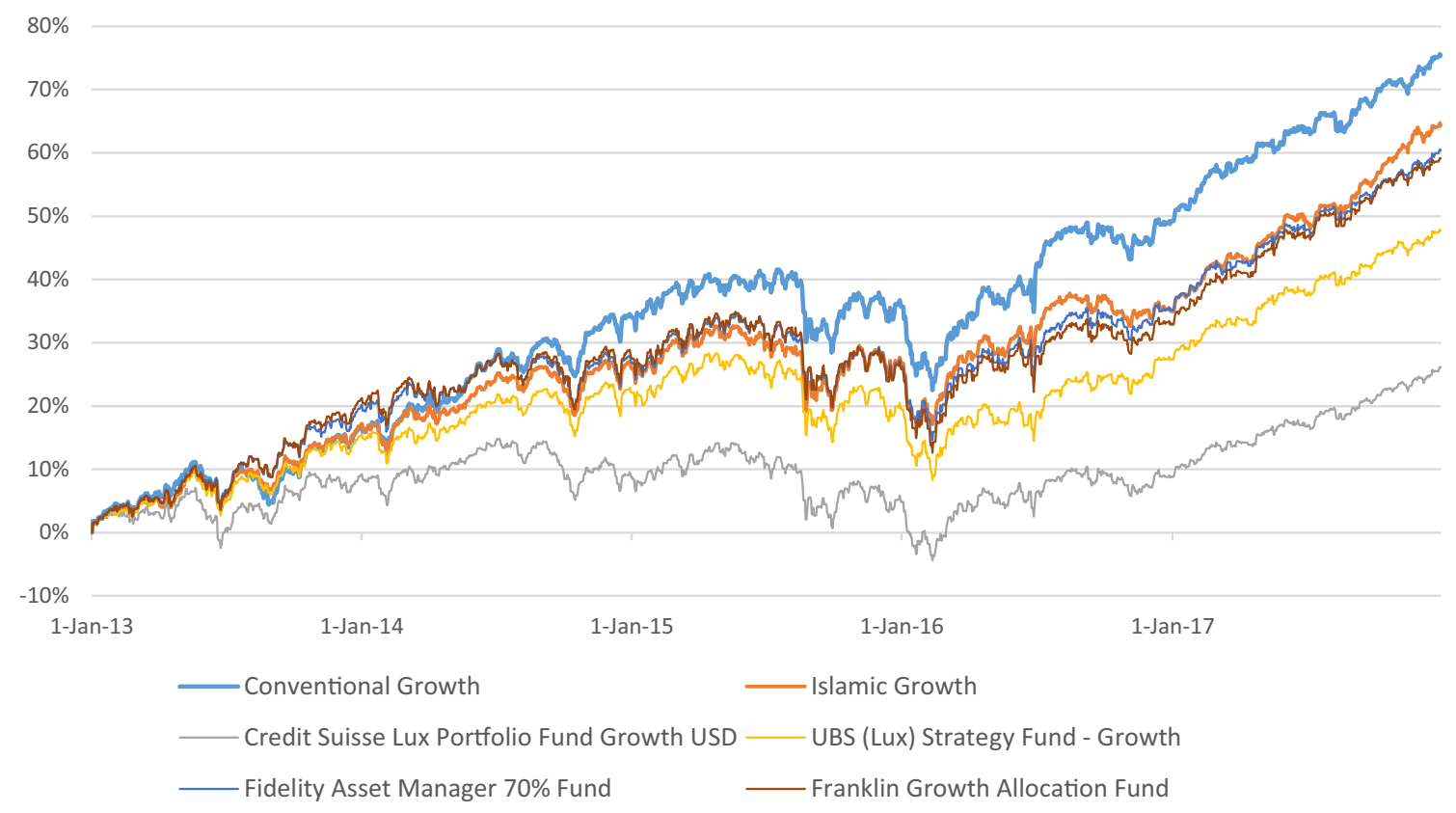

Fig. 3 5-year performance of an optimized Islamic (passive) growth, conventional (passive) versus conventional peers. Source: Authors' work, data from Bloomberg, dated 31 December 2017 
Table 11 Performance, risk and return: Islamic Growth (passive), conventional growth (passive) and peer mutual funds. Source: Authors' work, data from Bloomberg, dated 31 December 2017

\begin{tabular}{|c|c|c|c|c|c|}
\hline 5 Years beginning 01/01/2013 & $\begin{array}{c}\text { Islamic } \\
\text { Portfolio } \\
\text { (Active) } \\
\end{array}$ & $\begin{array}{c}\text { Credit Suisse Lux } \\
\text { Portfolio Fund } \\
\text { Growth } \\
\end{array}$ & $\begin{array}{l}\text { UBS (Lux) Strategy } \\
\text { Fund - Growth }\end{array}$ & $\begin{array}{c}\text { Fidelity Asset } \\
\text { Manager 70\% Fund }\end{array}$ & $\begin{array}{l}\text { Franklin Growth } \\
\text { Allocation Fund }\end{array}$ \\
\hline \multicolumn{6}{|l|}{ Return } \\
\hline Total Return & $68.51 \%$ & $26.07 \%$ & $47.65 \%$ & $60.36 \%$ & $59.12 \%$ \\
\hline Total Return (Annualized) & $11.01 \%$ & $4.75 \%$ & $8.03 \%$ & $9.70 \%$ & $9.60 \%$ \\
\hline Maximum Return (Monthly) & $1.85 \%$ & $2.00 \%$ & $1.65 \%$ & $1.83 \%$ & $2.11 \%$ \\
\hline Minimum Return (Monthly) & $-3.09 \%$ & $-3.22 \%$ & $-2.85 \%$ & $-3.23 \%$ & $-3.81 \%$ \\
\hline Mean Return (Annualized) & $11.32 \%$ & $5.07 \%$ & $8.41 \%$ & $10.30 \%$ & $10.19 \%$ \\
\hline \multicolumn{6}{|l|}{ Risk } \\
\hline Standard Deviation (Annualized) & $6.31 \%$ & $6.65 \%$ & $6.34 \%$ & $7.19 \%$ & $7.72 \%$ \\
\hline Skewness & $-0.70 \%$ & $-0.72 \%$ & $-0.57 \%$ & $-0.62 \%$ & $-0.72 \%$ \\
\hline VaR 95\% (ex-post) & $-0.64 \%$ & $-0.65 \%$ & $-0.64 \%$ & $-0.73 \%$ & $-0.77 \%$ \\
\hline \multicolumn{6}{|l|}{ Risk/Return } \\
\hline Sharpe Ratio & 1.23 & 0.91 & 0.91 & 0.98 & 0.91 \\
\hline Jensen Alpha & 2.39 & -2.21 & 0.49 & 0.88 & 0.31 \\
\hline Information Ratio & 0.72 & -0.99 & -0.09 & 0.43 & 0.38 \\
\hline Treynor Measure & 0.09 & 0.04 & 0.07 & 0.07 & 0.06 \\
\hline Beta (ex-post) & 0.89 & 0.93 & 0.87 & 1.03 & 1.11 \\
\hline Correlation & 0.9390 & 0.9295 & 0.9142 & 0.9488 & 0.9533 \\
\hline Capture Ratio & 0.82 & 0.86 & 0.79 & 0.96 & 1.03 \\
\hline
\end{tabular}

Source: Authors' work, data from Bloomberg, date 31 December 2017

\section{Discussion and findings}

This study set out to define the process of what may be considered Islamic asset management and then to examine the results. The first step was to determine whether classical asset management theory did or did not incorporate spiritual constraints of concern to Muslims. It was determined the foundation theories of asset management have no spiritual components objectionable to Islam.

What is clear, however, is that portfolio constraints are made based on moral choices that limit the investible universe. The result of constrained investing is most visible in the process of security selection. The processes of asset management underpinned by theory is otherwise not altered for constrained investing.

Constraints made by sharia principles are straightforward: no investments that incorporate interest, insuring investing is done in the real economy, and avoiding activities deemed repugnant to Islam (e.g., alcohol, pork, gambling). As an aside, one can see the parallels between sharia-compliant and SRI and ESG investing, both of which share many of the same precepts as sharia-compliant investing.
This study measured near-equal and superior performance of Islamic portfolios compared to various conventional peers. Why? Because real-world investors normally have a large majority of portfolio holdings in bonds and stocks regardless of investment strategy, we can look at their Islamic equivalents (sukuk for bonds, and sharia-compliant equities for stocks) for hints that may suggest the cause. Intuitively, guesses based on sharia screening can be made:

1. Sharia requires a direct line of sight with tangible assets that underlie fixed-income securities, ideally actual ownership, and cannot rely solely on the full faith and credit of the issuer (issuer guarantee). This may act as a credit enhancement due to improved collateral rights, thus implying reduced volatility in Islamic fixed income

2. Well-known restrictions on pork, alcohol, etc., have little impact on reducing the sharia equity universe. The biggest reduction is from removing all financials and heavily indebted companies. These are arguably more volatile. Removing them may imply lower equity volatility

3. Sharia requires "real economy" assets, which means excluding securities with no underlying tangible assets 
such as derivatives and structured products. Given the implied higher volatility of many derivatives, there may be a positive contribution from removing them

While these characteristics of sharia-compliant investment securities seem intuitively correct, they lack the statistical proofs sufficient to support the hypothesis for superior performance.

The results above indicate Islamic portfolios have the potential to stand shoulder-to-shoulder with their conventional (non-Islamic) peers according to common industry metrics. The passive and proxy-active Islamic portfolios outperformed the conventional peer mutual funds in nearly every risk and return metric. The only portfolio with superior overall metrics was the conventional construction, but even then the variance was not overly substantial.

\section{Limitations and future study}

While Islamic finance has grown substantially, with over $\$ 2.5$ trillion in assets at end-2018, the subset of activity called Islamic asset management is trivial. The results here are derived from a relatively small Islamic investible universe, almost incomparable to the choices for conventional investors.

The small size reflects the infancy of Islamic asset management. Demand will not be met until there is supply, and until now there are no asset managers almost anywhere providing a holistic Islamic asset management service. And, this infancy explains the lack of track record of Islamic asset managers, forcing any such study to rely on hypothetical constructions.

The infancy of Islamic asset management reflects also a near across-the-board need for further study. While past studies fairly well represent the Islamic equity markets, there is almost nothing on other asset categories and, until now, no rigorous study was made on multi-asset portfolio investing.

Despite these limitations, this study indicates that global, multi-asset-class, sharia-compliant portfolio constructions are more than just a theoretical construct. They can and perhaps should be real-world applications in the global asset management industry. The results can bring benefit to both consumers and providers of asset management services.

Funding Open access funding provided by Danube University Krems University for Continuing Education.

Open Access This article is licensed under a Creative Commons Attribution 4.0 International License, which permits use, sharing, adaptation, distribution and reproduction in any medium or format, as long as you give appropriate credit to the original author(s) and the source, provide a link to the Creative Commons licence, and indicate if changes were made. The images or other third party material in this article are included in the article's Creative Commons licence, unless indicated otherwise in a credit line to the material. If material is not included in the article's Creative Commons licence and your intended use is not permitted by statutory regulation or exceeds the permitted use, you will need to obtain permission directly from the copyright holder. To view a copy of this licence, visit http://creativecommons.org/licenses/by/4.0/.

\section{References}

Bahloul, Slah, Mourad Mroua, and Nader Naifar. 2017. Further Evidence on International Islamic and Conventional Portfolios Diversification under Regime Switching. Applied Economics 49 (39): 3959-3978. https://doi.org/10.1080/00036846.2016.1273496.

Black, Fischer, and Robert Litterman. 1992. Global Portfolio Optimization. Financial Analysts Journal 48 (5): 28-43. https://doi. org/10.2469/faj.v48.n5.28.

Brinson, G.P., L.R. Hood, and G.L. Beebower. 1986. Determinants of Portfolio Performance. Financial Analysts Journal 1986: 39-44.

Camgoz, C., K.Ahmed Kose, and Belkis Seval. 2019. Risk and Return Characteristics of Islamic Indices: An Empirical Approach. Istanbul Business Research 47 (2): 124-153. https://doi.org/10.26650 /ibr.2018.47.2.0008.

Dewandaru, G., Rumi Masih, Obiyathulla Bacha, and Mansur Masih. 2014. The Role of Islamic Asset Classes in the Diversified Portfolios: Mean Variance Spanning Test. Lancaster, UK. https://mpra. ub.uni-muenchen.de/56857/.

Dewi, Miranti Kartika, and Ilham Reza Ferdian. 2012. Evaluating Performance of Islamic Mutual Funds in Indonesia and Malaysia. Journal of Applied Economics and Business Research 2 (1): 11-33.

Fama, Eugene F. 1970. Efficient Capital Markets: A Reivew of Theory and Empirical Work. The Journal of Finance 25 (2): 383-417.

$\mathrm{Fu}$, Yufen, Danika Wright, and George Blazenko. 2019. Ethical Investing has No Portfolio Performance Cost. Research in International Business and Finance 52: 1-17. https://doi.org/10.1016/j.ribaf .2019.101117.

Hakim, Shabir Ahmad, Zarinah Hamid, and Ahamed Kameel Mydin Meera. 2016. Capital Asset Pricing Model and Pricing of Islamic Financial Instruments. Journal of King Abdulaziz University, Islamic Economics 29 (1): 21-39. https://doi.org/10.4197/Islec .29-1.2.

Hakim, Sam, and Manochehr Rashidian. 2004. How Costly is Investors' Compliance with Sharia? In ERF Eleventh Annual Conference. https://ejournal.narotama.ac.id/files/_How_Costly_is_Inves tors'_Compliance_to_Sharia.pdf.

Hassan, M.Kabir, Andrea Paltrinieri, Alberto Dreassi, Stefano Miani, and Alex Sclip. 2018. The Determinants of Co-movement Dynamics Between Sukuk and Conventional Bonds. Quarterly Review of Economics and Finance 68: 73-84. https://doi.org/10.1016/j. qref.2017.09.003.

Hazny, M.H., H.B.M. Hasim, and A.Y. Yusof. 2017. Mathematical Modelling of a Shariah-Compliant Capital Asset Pricing Model. Journal of Islamic Accounting and Business Research. https://doi. org/10.1108/JIABR-07-2016-0083.

Kumar, By Neeraj, Veronique Menou, Stuart Doole, and Laura Nishikawa. 2018. An Approach to ESG Strategic Tilting An Approach to ESG Strategic Tilting. Investments and Wealth Monitor.

Markowitz, H. 1952. Portfolio Selection*. The Journal of Finance 7 (1): 77-91. https://doi.org/10.1111/j.1540-6261.1952.tb01525.x.

Mosaid, Fadma El, and Rachid Rachid Boutti. 2014. Sukuk and Bond Performance in Malaysia. International Journal of Economics and Finance 6 (2): 226-235. https://doi.org/10.5539/ijef.v6n2p226.

Naifar, Nader, Mourad Mroua, and Slah Bahloul. 2017. Do Regional and Global Uncertainty Factors Affect Differently the Conventional Bonds and Sukuk? New Evidence. Pacific Basin Finance Journal 41: 65-74. https://doi.org/10.1016/j.pacfin.2016.12.004. 
Sharpe, William F. 1964. Capital Asset Prices: A Theroy of Market Equilibrium Under Conditions of Risk. Journal of Finance 19 (3): 425-442. https://doi.org/10.2307/2329297.

Tobin, James. 1958. Liquidity Preference as Behavior Towards Risk. The Review of Economic Studies 25 (2): 65-86.

Walkshäusl, Christian, and Sebastian Lobe. 2012. Islamic Investing. Review of Financial Economics 21 (2): 53-62. https://doi. org/10.1016/j.rfe.2012.03.002.

Publisher's Note Springer Nature remains neutral with regard to jurisdictional claims in published maps and institutional affiliations.

Dr. John A. Sandwick has been a Swiss private banker since 1993. He was formerly withDeutsche Bank (Suisse) S.A., Banque Leu S.A., and operated Encore Management S.A. Since2012 he has been developing Islamic wealth and asset management through the Safa
InvestmentServices brand. Dr. Sandwick has been a guest lecturer at the graduate school of finance,University Paris-Dauphine, and delivered Master Classes in Islamic asset management inMalaysia, Saudi Arabia, Kazakhstan, Switzerland and London. He has a Master's inDevelopment Banking from American University in Washington, D.C., and a Doctor in BusinessAdministration from Grenoble Ecole de Management.

Prof. Dr. Pablo Collazzo has an extensive professional and academic experience at the interplayof strategy and finance. He is Managing Partner of Sequoia, a global consulting firm, whileactive in academia, as Professor at Danube University, and Affiliate Faculty and Council Chairof the MOC Network at Harvard Business School. A former Rector of Universidad del Pacíficoin Ecuador, he was Academic Director of the European Academy of Business in Society inBrussels, after an international career in investment banking (Merrill Lynch) and consulting $(\mathrm{PwC})$. His academic background is in law and economics, with graduate studies at BostonUniversity (MBA) and ESADE (PhD). 